\author{
Arkadiusz Trzos ${ }^{a, b)^{*}}$, Wiktoria Kudłac), Karol Łyzińskia, d), Michał Korman ${ }^{c)}$
}

\author{
a) Jagiellonian University Medical College, Faculty of Medicine, Chair of Anaesthesiology and Intensive Care, Department of Disaster \\ Medicine and Emergency Care / Uniwersytet Jagielloński Collegium Medicum, Wydział Lekarski, Katedra Anestezjologii i Intensywnej \\ Terapii, Zakład Medycyny Katastrof i Pomocy Doraźnej \\ b) Atmed Medicine and Education / Atmed Medycyna i Edukacja \\ c) Jagiellonian University Medical College, Faculty of Medicine, Chair of Anaesthesiology and Intensive \\ Care, Extreme and Disaster Medicine Student Society / Uniwersytet Jagielloński \\ Collegium Medicum, Wydział Lekarski, Katedra Anestezjologii i Intensywnej Terapii, \\ Studenckie Koło Naukowe Medycyny Ekstremalnej i Medycyny Katastrof \\ d) Krakow Emergency Medical Services / Krakowskie Pogotowie Ratunkowe \\ * Corresponding author / Autor korespondencyjny: a.trzos@uj.edu.pl
}

\title{
Health Effects of Exposure to lonising Radiation
}

\section{Skutki zdrowotne ekspozycji na promieniowanie jonizujące}

\begin{abstract}
Purpose: The effects of ionising radiation on the human body has been discussed. The authors believe that the understanding of the radiation incidents from the perspective of its effects is crucial for better preparation, and therefore safer and more effective responses to incidents involving such threats. Introduction: The increasing use of radioactive materials and radiation producing devices in many areas of our lives carries the risk of exposure to high doses of radiation being hazardous to our health due to possible damage to radiation sources or improper handling. Exposure resulting from the intentional use of radioactive materials for criminal or terrorist purposes cannot be excluded, either. Exposure to ionising radiation may cause adverse health effects both to victims of a radiation incident and for rescuers providing emergency care. Such threats require the proper preparation of emergency medical services (EMS). Part of these preparations is to examine the specifics of radiation hazards, including radiation sources, the mechanism of injury of ionising radiation and the type of radiation damage.

Methodology: The publication presents the properties of ionising, corpuscular and electromagnetic types of radiation, which are the most important from EMS's perspective. The dangers of contact with a radiation source, the problem of external and internal contamination, the estimation of the amount of absorbed radiation were discussed, and the interrelationships between them were presented. The mechanism of direct and indirect action of ionising radiation on cell structures (DNA, mRNA, cytoplasmic membranes) and intracellular enzymes was thoroughly discussed. The authors presented health consequences of radiation for the body in the form of acute (deterministic) lesions and late (stochastic) lesions.

Conclusions: Particular attention was paid to acute radiation syndrome (ARS). The dependence of ARS on the amount of absorbed radiation was discussed in detail. Four stages of ARS were presented: initial, latent, manifest illness and recovery (or death) as well as the time of their onset, duration and end. The mechanism of damage to individual organs and systems was also analysed. The most common symptoms, their severity, and causes of life-threatening conditions, resulting from radiation damage in particular syndromes of ARS, were indicated. In addition to systemic effects, local changes in the form of Cutaneous Radiation Syndrome (CSR) were discussed.

Keywords: ionising radiation, deterministic effects, acute radiation syndrome, stochastic effects

Type of article: review article
\end{abstract}

Received: 30.12.2019; Reviewed: 15.03.2020; Accepted: 11.05.2020;

Authors' ORCID IDs: A. Trzos - 0000-0002-4390-0901; W. Kudła - 0000-0002-0072-0652; K. Łyziński - 0000-0003-3292-2459;

M. Korman - 0000-0003-1511-0774;

Percentage contribiution: A. Trzos - 50\%; W. Kudła - 25\%; K. Łyziński - 15\%; M. Korman - 10\%;

Please cite as: SFT Vol. 55 Issue 1, 2020, pp. 32-47, https://doi.org/10.12845/sft.55.1.2020.3;

This is an open access article under the CC BY-SA 4.0 license (https://creativecommons.org/licenses/by-sa/4.0/).

\section{ABSTRAKT}

Cel: W publikacji omówiono skutki działania promieniowania jonizującego na organizm ludzki. W przeświadczeniu autorów przedstawienie problematyki zdarzeń radiacyjnych od strony skutków napromieniowania pozwoli na lepsze przygotowanie na wypadek ich wystąpienia, a w konsekwencji bezpieczniejsze działanie w trakcie tego zagrożenia. 
Wprowadzenie: Coraz szersze zastosowanie materiałów promieniotwórczych i urządzeń wytwarzających promieniowanie jonizujące w wielu obszarach naszego życia niesie za sobą ryzyko narażenia na działanie niebezpiecznych dla zdrowia dawek promieniowania. Dawki te mogą być generowane wskutek uszkodzenia źródeł promieniowania lub postępowania z nimi w nieodpowiedni sposób. Nie można również wykluczyć narażeń wynikających z intencjonalnego wykorzystania materiałów promieniotwórczych w działaniach kryminalnych lub terrorystycznych. Narażenie na promieniowanie jonizujące może wywołać negatywne skutki zdrowotne - zarówno u ofiar zdarzenia radiacyjnego, jak i u ratowników udzielających ofiarom pomocy. Istniejące zagrożenia wymagają więc odpowiedniego przygotowania medycznych służb ratowniczych. Jednym z elementów tych przygotowań jest poznanie specyfiki zagrożeń radiacyjnych, w tym źródeł promieniowania, mechanizmu działania poszczególnych form promieniowania jonizującego, a także rodzaju obrażeń radiacyjnych, które wywołują.

Metodologia: W artykule przedstawiono właściwości promieniowania jonizującego, najbardziej istotne z punktu widzenia ratownictwa medycznego. Omówiono zagadnienia związane z kontaktem ze źródłem promieniowania, skażenia zewnętrznego i wewnętrznego, pomiaru wielkości ekspozycji i dawek pochłoniętych oraz zaprezentowano wzajemne zależności pomiędzy nimi. Szczegółowo opisano mechanizm bezpośredniego i pośredniego działania promieniowania jonizującego na struktury komórkowe (DNA, mRNA, błony cytoplazmatyczne) i enzymy wewnątrzkomórkowe. Przedstawiono konsekwencje zdrowotne dla organizmu w postaci uszkodzeń ostrych (deterministycznych) i zmian późnych (stochastycznych).

Wnioski: Szczególną uwagę zwrócono na ostry zespół radiacyjny (ang. Acute Radiation Syndrome, ARS). Szczegółowo omówiono zależność poszczególnych postaci ARS od wielkości pochłoniętej dawki. Przedstawiono każdą z faz ARS: wstępną, utajoną, rozwiniętych objawów i zdrowienia (śmierci) oraz czas ich wystąpienia, długość trwania i moment zakończenia. Scharakteryzowano mechanizm uszkodzenia poszczególnych narządów i układów. Wskazano najczęstsze objawy, ich nasilenie i przyczyny zagrożenia życia w poszczególnych postaciach ARS. Obok skutków ogólnoustrojowych opisano zmiany miejscowe pod postacią radiacyjnego zespołu skórnego (ang. Cutaneous Radiation Syndrome, CSR).

Typ artykułu: artykuł przeglądowy

Słowa kluczowe: promieniowanie jonizujące, skutki deterministyczne, ostry zespół radiacyjny, skutki stochastyczne

Przyjęty: 30.12.2019; Zrecenzowany: 15.03.2020; Zaakceptowany: 11.05.2020;

Identyfikatory ORCID autorów: A. Trzos - 0000-0002-4390-0901; W. Kudła-0000-0002-0072-0652;

K. Łyziński - 0000-0003-3292-2459; M. Korman - 0000-0003-1511-0774;

Procentowy wkład merytoryczny: A. Trzos - 50\%; W. Kudła - 25\%; K. Łyziński - 15\%; M. Korman - 10\%;

Proszę cytować: SFT Vol. 55 Issue 1, 2020, pp. 32-47, https://doi.org/10.12845/sft.55.1.2020.3;

This is an open access article under the CC BY-SA 4.0 license (https://creativecommons.org/licenses/by-sa/4.0/).

\section{Introduction}

lonising radiation has been present since the beginning of the Universe. The early Earth was penetrated by much higher radiation than that we are exposed to now. The composition of the Earth's crust with deposits of radioactive elements incl. uranium, thorium, radium has been a major source of natural radiation [1]. Part of natural radiation emanates from the ground, which is called background radiation and its values differ. The average annual dose in Poland is $2.43 \mathrm{mSv}$ from natural sources [2]. In numerous European countries average natural background exposure is higher e.g. in Norway, Switzerland, Finland and Spain. In some parts of Norway and Sweden natural exposure ranges from 10 to $35 \mathrm{mSv}$ per annum, but it is not the highest value in the world, as there are areas where even higher natural exposure has been observed. In Ramsar, a city in Iran, annual radiation exposure equals $132 \mathrm{mSv}$ per year, whereas the maximum allowable annual dose of radiation for employees is $20 \mathrm{mSv}$ [1], [3]. In general, the indoor radiation may be higher than the outdoor one. Grand Central Station in New York produces radiation of $5.4 \mathrm{mSv}$ per year (due to the use of granite containing high concentrations of radioactive elements) [3].

All living organisms consist in radioactive elements, and that is why every organism emits radiation. For instance, a human being is a source of radiation due to radioactive potassium present in his or her body. It makes up $0.012 \%$ of the total amount of potassium, which is the source of radiation of $0.17 \mathrm{mSv}$ per year [4-6]. Another source of radiation is cosmic radiation, which is mostly

\section{Wprowadzenie}

Promieniowanie jonizujące występuje od początków istnienia wszechświata. Gdy dopiero powstawało życie na Ziemi, wartości tego promieniowania były znacznie wyższe od występujących obecnie. Do dzisiaj w skorupie ziemskiej znajdują się pierwiastki promieniotwórcze, m.in. uran, tor, rad, które są źródłem naturalnego promieniowania [1]. Jego część dociera do nas z podłoża gruntowego. Stanowi ono tak zwane tło Ziemi. Promieniowanie to przyjmuje różne wartości, w Polsce wynosi przeciętnie 2,43 mSv [2]. W wielu krajach europejskich wartość ta jest jednak wyższa, np. w Norwegii, Szwecji, Szwajcarii, Finlandii, Hiszpanii. W pewnych rejonach Norwegii i Szwecji promieniowanie ze źródeł naturalnych jest szczególnie wysokie, wynosi bowiem od 10 do $35 \mathrm{mSv} /$ rok. Ponadto na świecie spotyka się obszary o jeszcze wyższym promieniowaniu tła Ziemi. W mieście Ramsar (Iran) roczna dawka promieniowania sięga nawet $132 \mathrm{mSv} /$ rok, podczas gdy dopuszczalna dawka, na którą mogą być narażeni irańscy pracownicy wynosi $20 \mathrm{mSv}$ rocznie [1], [3]. Wartość promieniowania w obiektach z reguły jest wyższa od tych spotykanych na wolnym powietrzu. Przykładowo w budynku stacji kolejowej Grand Central w Nowym Jorku dawka promieniowania wynosi aż $5,4 \mathrm{mSv} /$ rok (z powodu użycia podczas budowy granitu, w którym znajdują się izotopy promieniotwórcze) [3].

Pierwiastki radioaktywne stanowią również element budulcowy żywego organizmu. Stąd każdy organizm emituje pewne wartości promieniowania jonizującego. Przykładowo, człowiek jest źródłem promieniowania jonizującego wynikającego z obecności 
absorbed by the Earth's atmosphere and only its small fraction reaches the Earth's surface. The level of cosmic radiation dose in Poland is merely $11.8 \%$ of the total annual dose [7].

The development of civilization and subsequent scientific and technological advances allowed for the use of radioactive materials for both peaceful and military purposes. The radiation technologies are commonly used in various industries esp. energy industry, transportation industry and medicine, but the use of those technologies poses risks. Radionuclides may carry a health risk for people resulting from various incidents such as accidental man-made releases (Mexico, Goiânia) or largescale radiation accidents (Chernobyl, Fukushima). Radiation may also be used intentionally for military, criminal or terrorist purposes (poisoning Alexander Litvinenko).

A statistical resident of Poland receives radiation in the annual average dose of $3.74 \mathrm{mSv}$, of which $2.43 \mathrm{mSv}$ comes from natural radiation and $1.31 \mathrm{mSv}$ from artificial sources [2]. Radiation from medical exposure especially computed tomography scans (CT) is an increasing man-made radiation source [8]. A single chest CT scan delivers $3 \mathrm{mSv}$, which is equivalent to the radiation dose of 150 chest $X$-rays while a head CT scan equals $4 \mathrm{mSv}$, which corresponds to 200 chest X-rays [9]. According to radiation regulations and laws, an average person may receive an effective dose of $1 \mathrm{mSv}$ per a single calendar year. An effective dose may be greater than $1 \mathrm{mSv}$ unless a total dose of $5 \mathrm{mSv}$ in 5 consecutive years is not exceeded [10]. The authors are inclined to believe that due to a common use of radioactive materials and related risks it carries, the understanding of ionising radiation effects on a human body should be paramount for EMS workers. The aim of this paper is to present the impact of ionising radiation on a human body and health effects of highdose radiation. w organizmie radioaktywnego potasu. Stanowi on ok. 0,012\% całkowitej zawartości potasu, będąc źródłem dawki promieniowania na poziomie $0,17 \mathrm{mSv}$ rocznie [4-6]. Dodatkowo z kosmosu dociera do nas kolejna dawka promieniowania. Na szczęście atmosfera pochłania znaczną część promieniowania kosmicznego i tylko niewielka jego część przedostaje się do powierzchni Ziemi. Na terenie Polski wartość dawki pochodzącej z promieniowania kosmicznego stanowi jedynie 11,8\% całkowitej dawki rocznej [7].

Rozwój cywilizacyjny i związany z nim postęp naukowo-techniczny pozwoliły na wykorzystywanie materiałów promieniotwórczych w celach zarówno pokojowych, jak i militarnych. Z właściwości promieniowania korzystają różne dziedziny $\mathrm{m}$. in. energetyka, transport, przemysł czy medycyna, jednak z wykorzystywaniem źródeł promieniowania wiąże się pewne niebezpieczeństwo. Materiały promieniotwórcze mogą stanowić dla człowieka zagrożenie, np. gdy w wyniku ludzkiej nieodpowiedzialności dojdzie do przypadkowego ich uwolnienia (Meksyk, Goiânia). Mogą to być zdarzenia na ogromną skalę (Czarnobyl, Fukushima). Promieniowanie bywa też wykorzystane intencjonalnie do celów militarnych, kryminalnych lub terrorystycznych (otrucie Aleksandra Litwinienki).

Współcześnie przeciętny Polak, otrzymując średnio rocznie dawkę promieniowania w wysokości $3,74 \mathrm{mSv}$, pochłania promieniowanie ze źródeł naturalnych o wartości $2,43 \mathrm{mSv}$, a ze źródeł sztucznych - 1,31 mSv [2]. Coraz większy odsetek promieniowania pochodzącego ze źródeł sztucznych pochodzi z badań medycznych, głównie tomografii komputerowej (TK) [8]. Badanie TK klatki piersiowej wiąże się z pochłonięciem przez pacjenta dawki promieniowania rzędu $3 \mathrm{mSv}$, co stanowi odpowiednik dawki ze 150 zdjęć rentgenowskich klatki piersiowej, a badanie TK głowy - $4 \mathrm{mSv}$, czyli równości promieniowania przy 200 zdjęciach rentgenowskich klatki piersiowej [9]. Według obowiązujących przepisów przeciętny obywatel ze źródeł zewnętrznych może otrzymać dawkę $1 \mathrm{mSv}$ promieniowania $w$ ciągu roku kalendarzowego. Jej przekroczenie $w$ danym roku kalendarzowym możliwe jest pod warunkiem, że w ciągu kolejnych pięciu lat kalendarzowych jej sumaryczna wartość nie sięgnie powyżej $5 \mathrm{mSv}$ [10]. W dobie powszechnego wykorzystania materiałów promieniotwórczych (i ryzyka z tym związanego), znajomość skutków działania promieniowania jonizującego na organizm człowieka - w ocenie autorów - powinna być powszechną wiedzą pracowników systemu ratowniczego. Celem publikacji jest przedstawienie sposobu oddziaływania promieniowania jonizującego na organizm ludzki oraz omówienie klinicznych następstw napromieniowania dużymi dawkami.

\section{Promieniowanie jonizujące}

W szerokim spektrum promieniowania spotykanego w otoczeniu człowieka występuje promieniowanie jonizujące. Jest to forma energii wysyłana w postaci cząstek lub fali elektromagnetycznej, powodująca $w$ organizmie powstawanie niebezpiecznych dla zdrowia i życia jonów.

Istnieje kilka form promieniowania jonizującego, różniących się od siebie właściwościami, takimi jak: zasięg, przenikliwość, zdolność do jonizacji.

- Cząstki alfa (jądra helu) mają zasięg ok. $10 \mathrm{~cm}$ w powietrzu. 
thousandfold in human tissues. A thin shield e.g. a sheet of paper can effectively stop the penetration of alpha particles [11, p. 688];

- Beta radiation (electrons and positrons) - the range is up to 10 metres in the air with high energies. Beta particles may be absorbed by thicker shielding e.g. aluminum plate [12];

- Gamma radiation and X-radiation (electromagnetic waves) - highly penetrating and its range is virtually unlimited in the air. It requires thick shields of concrete or heavy metals e.g. lead [3], [12];

- Neutron radiation (neutron particles) - highly penetrating and thick shields of concrete or water are used to absorb it [12].

Ionising radiation protection is presented in Figure 1.
Zmniejsza się on tysiąckrotnie w tkankach ludzkiego ciała. Do ochrony przed tego typem promieniowania wystarczy cienka osłona (np. kartka papieru) [11, s. 668];

- Promieniowanie beta (cząstki elektronów i pozytonów) przy dużej wartości energii promieniowania ma zasięg nawet do dziesięciu metrów w powietrzu. Ochrona wymaga zastosowania grubszych osłon (np. blaszki aluminiowej) [12];

- Promieniowania gamma i rentgenowskie (fale elektromagnetyczne) są mocno przenikliwe, mając praktycznie nieograniczony zasięg w powietrzu. Ochronę stanowią grube osłony z betonu lub metali ciężkich (np. z ołowiu) [3], [12];

- Promieniowanie neutronowe (cząstki neutronów) również ma bardzo dużą przenikliwość. Do jego zatrzymania wykorzystywane są grube warstwy betonu oraz bloki wodne [12].

Możliwości osłony przed promieniowaniem jonizującym przedstawiono na rycinie 1 .

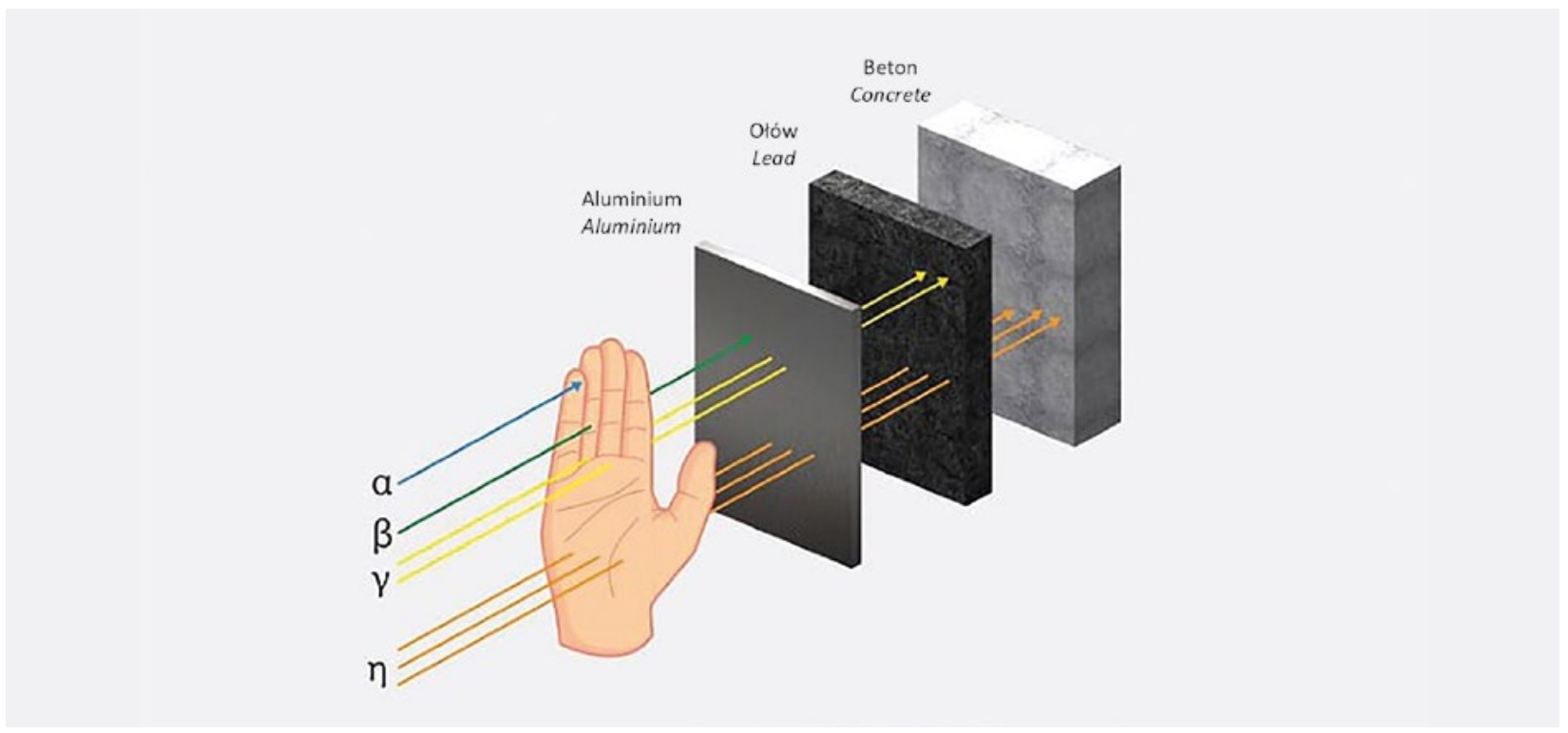

Figure 1. Radiation shielding

Rycina 1. Ochrona przed promieniowaniem radiacyjnym

Source: Own elaboration.

Żródło: Opracowanie własne.

The source of radiation may be any material including radioactive isotopes or ionising radiation-producing devices e.g. X-ray machines, CT scanners. Radioactive sources are divided into a sealed source, in which the radioactive material is prevented from escaping or being released and an unsealed (closed) source, which refers to any radioactive material which is not encapsulated or contained [13]. Radioactive liquids or solids that come in direct contact with people cause external contamination. Internal contamination occurs when radioactive material is inhaled, ingested or incorporated via wounds. Radiation producing devices (e.g. X-ray machines, CT scanners) do not cause contamination.
Źródłem promieniowania może być materiał zawierający w swoim składzie izotop promieniotwórczy lub urządzenie generujące (wytwarzające) promieniowanie jonizujące, np. aparat rentgenowski, tomograf komputerowy. Źródła promieniowania zawierające materiał promieniotwórczy dzieli się na zamknięte (takie, które chronią materiał promieniotwórczy przed wydostaniem się do środowiska) oraz otwarte (wszystkie pozostałe) [13]. Bezpośredni kontakt $z$ materiałem promieniotwórczym - zarówno $w$ formie stałej, jak i płynnej - powoduje skażenie zewnętrze. Wchłonięcie materiału promieniotwórczego przez drogi oddechowe lub przewód pokarmowy oraz wniknięcie bezpośrednio przez rany powoduje skażenie wewnętrzne. Aparaty generujące promieniowanie jonizujące (np. rentgenowskie, TK) nie powodują skażeń. 


\section{Radiation doses}

Since radiation is the energy deposited in matter, the knowledge of the absorbed doses by tissue is crucial to assess the risk of radiation effects. Radiation absorbed dose which is defined as one Joule of energy absorbed per kilogram of matter. The SI unit of measure is the gray (Gy). Owing to the fact that different ionising abilities refer to a specific type of radiation, an equivalent dose has been introduced. An equivalent dose is based on the absorbed dose to individual tissues or organs taking into account the type of radiation, and thereby the amount of energii and its force. An equivalent dose allows for precise assessment of biological damage of a certain type of radiation to exposed tissues. The SI unit of measure is the sievert (Sv). An effective dose is calculated by multiplying an absorbed dose (Gy) by a radiation weighting factor to a specified radiation type. The values radiation weighting factor are presented in Table 1. Gray and sievert are the units expressing high amounts of absorbed energy. Hence mili $(1 / 1000)$ and micro $(1 / 1000000)$ of the base unit $(1 \mathrm{~Sv}(\mathrm{~Gy})=1000 \mathrm{mSv}(\mathrm{Gy})=10000000 \mathrm{uSv}(\mathrm{Gy}))$ are used. In order to assess the variability of exposure in time a dose rate is given i.e. a dose per time unit e.g. $\mathrm{Gy} / \mathrm{h}$ or $\mathrm{Sv} / \mathrm{h}$ which is used to show radiation effects.

Table 1. The values of the radiation weighting factor

Tabela 1. Wartości współczynnika wagowego promieniowania

\section{Dawki promieniowania}

Jako że promieniowanie jest formą przekazywania energii, to znajomość wartości pochłoniętej energii przez tkankę jest niezbędna w ocenie ryzyka skutków napromieniowania. Dawka pochłonięta określana jest jako ilość energii pochłoniętej (mierzonej w dżulach) na kilogram masy tkanki. W układzie SI jednostką jest 1 grej (Gy). Ze względu na różne zdolności do jonizacji poszczególnych form promieniowania wprowadzono tzw. równoważnik dawki. Wartość ta mierzy dawkę pochłoniętą w tkance lub narządzie, uwzględniając rodzaj - a tym samym wielkość energii i moc działania - danego promieniowania. Pozwala to na dokładniejsze określenie skutków biologicznych oddziaływania danego promieniowania na eksponowaną tkankę. W układzie SI jednostką jest 1 siwert (Sv). Wartość tę otrzymuje się po przemnożeniu wartości dawki pochłoniętej (Gy) przez współczynnik wagowy promieniowania o wartości charakterystycznej dla danego rodzaju promieniowania. Wartości współczynnika wagowego promieniowania przedstawiono w tabeli 1 . Grej i siwert są to jednostki określające duże wartości pochłoniętej energii. W praktyce wykorzystywane są wartości mniejsze, mierzone w wartościach mili $(1 / 1000)$ czy mikro (1/1 000 000) wartości podstawowej (1Sv (Gy) = $1000 \mathrm{mSv}(\mathrm{Gy})=1000000 \mathrm{uSv}(\mathrm{Gy})$ ). W celu określenia zmienności ekspozycji w czasie podaje się moc dawki, tj. wartość dawki w przeliczeniu na jednostkę czasu (np. Gy/h czy Sv/h). Pojęcie to wykorzystywane jest przy określaniu skutków napromieniowania.
Radiation type /

Rodzaj promieniowania
$\mathrm{W}_{\mathrm{R}}$ 
Most of ionising radiation detection devices (e.g. Geiger Mueller (GM) Detectors) do not measure an absorbed dose but only an exposure dose, which is the amount of single ion pairs produced in a gas-filled chamber. The exposure dose is based on the amount of the total charge of the ions in air produced by photons of ionising radiation. The SI unit of exposure to radiation is $\mathrm{C} / \mathrm{kg}$ (coulomb/kilogram) and is the total electrical charges produced in a volume of air of mass. The unit for exposure has no name and is expressed as $\mathrm{C} / \mathrm{kg}$ and a previously used roentgen unit was related to $1 \mathrm{R}=2.58 \times 10^{-14} \mathrm{C} / \mathrm{kg}$. The exposure dose expresses exposure per hour ( $\mathrm{mSv} / \mathrm{h}$ ). In order to assess biological effects of radiation on the human body it is crucial to measure an absorbed dose or even an equivalent dose.

\section{Biological effects of irradiation}

lonising radiation-induced damages lead to local and systemic radiation lesions and injuries. Damage to biological material is the result of the energy deposited in particles of cellular structures. There are three phases of radiation influence on cells: physical, chemical and biological. In the physical phase, the radiation pushes an electron in the DNA molecule (strand of deoxyribonucleic acid) out of its orbit, which disrupts its structure. In the chemical phase, high energy induces ionisation (radiolysis) of water molecules $\left(\mathrm{OH}^{-}, \mathrm{H}+\right)$, which leads to the production of free radicals $\left(\cdot \mathrm{OH}, \mathrm{HO}_{2} \cdot\right)$ and chemical bonds are either broken or new ones are formed [14]. Free radicals damage cellular structures and thus cells in the biological phase. DNA, mRNA, enzymes (catalase, peroxidase) and cytoplasmic membranes are mainly damaged [15]. Some of those damages that are beyond repair lead to cell death or its lysis (decomposition and elimination). In other cases changes to DNA survive and may be passed to a subsequent cell generation.

Apart from the damage resulting from water radiolysis, there is an indirect damage resulting from the Compton Effect (Compton Scatter) and the photoelectric effect [16]. Two models of DNA chain damage are presented in Figure 2. Minor damage activate the self-repair mechanism in the cell. Radiation exposure above the threshold dose causes too much major and irreparable damage. This, in turn, activates apoptosis (the natural process of elimination of damaged cells) in the whole body [17]. If the cell DNA is not repaired then changes in genetic material due to radiation exposure survive. The DNA changes may result in passing new features/properties to the next generations and may trigger neoplastic changes.
Większość wykorzystywanych do pomiarów promieniowania jonizującego urządzeń (np. licznik Geigera-Müllera) nie mierzy dawki pochłoniętej, a jedynie dawkę ekspozycyjną, np. poprzez pomiar ilości par jonów wytworzonych w określonej objętości gazu. Dawka ekspozycyjna jest to wielkość oparta na liczbie aktów jonizacji wywołanych w powietrzu przez fotony promieniowania jonizującego. W układzie SI dawka ekspozycyjna wyrażana jest w C/kg (kulomb/kilogram) i określa sumę ładunków elektrycznych jednego znaku, generowanych przez promieniowanie w jednostce masy powietrza. Jednostka C/kg nie ma swojej nazwy, a z dawniej stosowaną jednostką rentgenem $R$ związana jest zależnością $1 \mathrm{R}=2,58 \times 10^{-14} \mathrm{C} / \mathrm{kg}$. Podobnie do mocy dawki pochłoniętej, ważnym parametrem jest moc dawki ekspozycyjnej określającej wartość ekspozycji na godzinę ( $\mathrm{mSv} / \mathrm{h}$ ). Kluczowe w ocenie skutków napromieniowania człowieka pozostaje jednak określenie wielkości dawki pochłoniętej, a najlepiej równoważnika tej dawki.

\section{Skutki biologiczne napromieniowania}

W wyniku oddziaływania na organizm żywy promieniowania jonizującego dochodzi w nim do powstania szeregu uszkodzeń, prowadzących do rozwoju miejscowych i ogólnych zmian chorobowych. Uszkodzenie materiału biologicznego jest wynikiem przekazania energii promieniowania do cząsteczek struktur komórkowych. Oddziaływanie promieniowania jonizującego na komórkę odbywa się w trzech fazach: fizycznej, chemicznej i biologicznej.

W fazie fizycznej dochodzi do wybicia elektronów z cząsteczki DNA (nici kwasu deoksyrybonukleinowego), co destabilizuje jej strukturę. W fazie chemicznej wystarczająco wysokie energie powodują jonizację (radiolizę) cząsteczek wody $(\mathrm{OH}-, \mathrm{H}+)$, a w konsekwencji powstawanie wolnych rodników $\left(\cdot \mathrm{OH}, \mathrm{HO}_{2}{ }^{\cdot}\right)$ i zrywanie lub tworzenie nowych wiązań chemicznych [14]. Oddziaływanie wolnych rodników $w$ fazie biologicznej powoduje uszkodzenie struktur komórkowych, a w konsekwencji - całych komórek. Dochodzi głównie do uszkodzenia DNA, mRNA, enzymów (katalaz i proteaz) i błon cytoplazmatycznych [15]. Część spośród uszkodzeń, które nie mogą zostać naprawione, doprowadza do śmierci komórki i jej lizy (rozpuszczenia i eliminacji). W pozostałych przypadkach dochodzi do zachowania zmian w DNA, przez co mogą one zostać przekazane przyszłym pokoleniom komórek.

Obok wspomnianych uszkodzeń powstałych w wyniku radiolizy wody dochodzi do uszkodzeń bezpośrednich w wyniku tzw. zjawiska Comptona (rozpraszania komptonowskiego) oraz zjawiska fotoelektrycznego [16]. Dwa mechanizmy uszkodzenia łańcucha DNA komórki zilustrowano na rycinie 2 . Powstałe niewielkie uszkodzenia powodują uruchomienie procesu naprawczego $w$ komórce. Przekroczenie progowej dawki promieniowania powoduje powstanie zbyt dużych uszkodzeń niemożliwych do naprawienia. Skutkuje to uruchomieniem procesów apoptotycznych (naturalnego procesu eliminacji uszkodzonych komórek) w skali całego organizmu [17]. Jeżeli nie dochodzi do naprawy DNA w komórce, to zmiany w materiale genetycznym powstałe $w$ wyniku napromieniowania komórki zostają zachowane. Powstałe zmiany w obrębie DNA niosą za sobą ryzyko przekazania nowych cech kolejnym pokoleniom oraz mogą prowadzić do powstania zmian nowotworowych. 


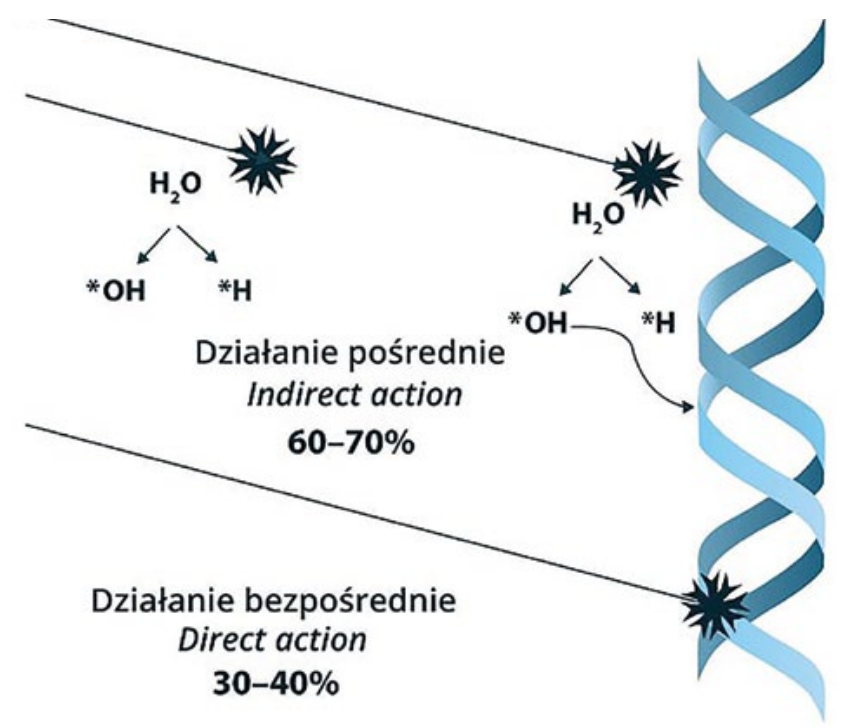

Figure 2. Mechanism of DNA chain damage by ionising radiation

Rycina 2. Mechanizm uszkodzenia łańcucha DNA przez promieniowanie jonizujące

Source / Źródło: Own elaboration based on: / Opracowanie własne na podstawie: M. H. Bourguignon, P. A. Gison, M. R. Perez, S. Michelin, D. Dubner, M. Di Giorgio, E. D. Carosella, Genetic and epigenetic features in radiation sensitivity: Part Il: Implications for clinical practice and radiation protection, "European Journal of Nuclear Medicine and Molecular Imaging" 2005, 32, 351-368 [41].

Prenatal ionising radiation exposure may be teratogenic (disturbing the embryo development), carcinogenic, or mutagenic. Health effects from radiation exposure depend on the radiation dose and the stage of embryonic development. An embryo is particularly sensitive to radiation during the period of organogenesis (two to seven weeks after conception) and in the early fetal period (eight to 15 weeks after conception) [18]. The effects of exposure to radiation may be classified as deterministic and stochastic ones.

\section{Deterministic effects}

Deterministic effects of ionising radiation result from exposure to radiation with a threshold dose exceeding $1 \mathrm{~Gy}$ delivered in a short period of time (a single dose). Irradiation above a threshold dose causes temporary or permanent damage to tissues and thus damage to the organs and systems. Deterministic effects most often occur from 2 to 4 weeks after the radiation exposure and are manifested as bone marrow (hematopoietic), gastrointestinal, cardiovascular [19]. Local reactions and skin lesions may occur alone or with general symptoms due to ionising radiation. Although many organs are in fact damaged, the signs and symptoms are varied, depending on the dose and on extent of the damage to the organs and systems.

Table 2 presents the damage to the human body caused by external radiation source. Internal irradiation resulting from unintentional or intentional contamination via inhalation, ingestion or through the wounds occurs rarely.
W życiu płodowym zarodka narażenie na promieniowanie jonizujące może być teratogenne (uszkodzenie płodu), rakotwórcze lub mutagenne. Efekty napromieniowania są bezpośrednio związane z poziomem ekspozycji i etapem rozwoju płodu. Płód jest najbardziej podatny na promieniowanie podczas organogenezy (2-7 tygodni po zapłodnieniu) i we wczesnym okresie płodowym (8-15 tygodni po zapłodnieniu) [18]. W związku z różnym wpływem promieniowania na organizm żywy możemy wyróżnić dwa podstawowe skutki działania promieniowania jonizującego: deterministyczne i stochastyczne.

\section{Skutki deterministyczne}

Skutki deterministyczne powstają w wyniku przyjęcia dużych, ponadprogowych tj. powyżej 1Gy, dawek promieniowania jonizującego w krótkim przedziale czasu (dawka jednorazowa). Napromienienie powyżej dawki progowej powoduje przejściowe lub trwałe uszkodzenia tkanek, a w konsekwencji uszkodzenie całych układów i narządów. Skutki deterministyczne pojawiają się najczęściej w okresie od 2 do 4 tygodni po narażeniu na promieniowanie. Manifestują się one w postaci ogólnoustrojowych zespołów klinicznych: szpikowego (hematopoetycznego), żołądkowo-jelitowego, naczyniowo-mózgowego [19]. Miejscowe odczyny i zmiany skórne mogą wystąpić samodzielnie lub równolegle z objawami ogólnymi, w następstwie ekspozycji na promieniowanie jonizujące. Chociaż w praktyce uszkodzenia w organizmie dotyczą wielu narządów, to manifestacja objawów jest różna i zależna od wielkości pochłoniętej dawki i skali uszkodzenia poszczególnych narządów i układów. 
Tabela 2 pokazuje, że uszkodzenia organizmu spowodowane są najczęściej promieniowaniem pochodzącym z zewnętrznego źródła. Sporadycznie spotyka się przypadki napromieniowania wewnętrznego, powstałego w wyniku zanieczyszczenia (kontaminacji) nieświadomego lub celowego, poprzez wdychanie, spożycie lub bezpośrednie wniknięcie przez uszkodzoną skórę.

Table 2. Characteristics of individual forms of acute radiation syndrome (ARS)

Tabela 2. Charakterystyka poszczególnych postaci ostrego zespołu radiacyjnego (ARS)

\begin{tabular}{|c|c|c|c|c|}
\hline $\begin{array}{l}\text { ARS subsyndrome / } \\
\text { Postać ARS } \\
\text { Dose value / } \\
\text { Wartość dawki }\end{array}$ & Symptoms / Objawy & $\begin{array}{l}\text { Death rate without me- } \\
\text { dical treatment / Śmier- } \\
\text { telność bez udzielenia } \\
\text { pomocy medycznej }\end{array}$ & $\begin{array}{c}\text { Death rate with } \\
\text { medical treatment / } \\
\text { Śmiertelność przy } \\
\text { udzieleniu pomocy } \\
\text { medycznej }\end{array}$ & $\begin{array}{c}\text { Death; Immediate } \\
\text { death cause /Śmierć; } \\
\text { Bezpośrednia przyczy- } \\
\text { na zgonu }\end{array}$ \\
\hline
\end{tabular}
in peripheral blood lymphocyte counts after several Faza subkliniczna days after exposure / Leukopenia lekka do umiarkowanej, zmęczenie, ogólne osłabienie, zmniejszenie (1-2 Gy) ilości leukocytów we krwi obwodowej występujące kilkanaście dni po napromieniowaniu
6-8 weeks / 6-8 tyg. Bone-marrow depression / Depresja układu odpornościowego
Hematopoietic syndrome / Postać hematopoetyczna
Mild or severe leukopenia, hemorrhage, infections, epilation (hair loss) after $3 \mathrm{~Gy}$, weakness and fatigue, drop in peripheral blood lymphocyte counts (lymphopenia) after a few days followed by anemia and immunodeficiency and hemorrhagic diathesis / Leukopenia umiarkowana lub silna, krwotok, infekcje, wypadanie włosów po $3 \mathrm{~Gy}$, ogólne osłabienie, zmniejszenie ilości limfocytów we krwi obwodowej (limfopenia) występujące kilka dni po napromieniowaniu później niedokrwistość i obniżenie odporności ustroju, niekiedy skaza krwotoczna
Severe leukopenia, high fever, dehydration, vomiting, electrolyte disturbances, hypotension, gastrointestinal reactions including bloody diarrhea, hemorrhagic diathesis, fluid and electrolyte imbalance accompanied by swelling; symptoms occur shortly or several hours after exposure / Silna leukopenia, wysoka gorączka, odwodnienie, wymioty, zaburzenia elektrolitowe, hipotensja, dominują objawy ze strony przewodu pokarmowego z charakterystycznymi krwawymi biegunkami, skaza krwotoczna oraz zaburzenia gospodarki wodno-elektrolitowej z obrzękami; objawy pojawiają się wkrótce po napromieniowaniu najpóźniej do kilkunastu godzin
2-4 weeks / 2-4 tyg Damage to gastrointestinal epithelium / Uszkodzenie nabłonka przewodu pokarmowego
Nausea, vomiting, heavy diarrhea, high temperature, electrolytes imbalance, convulsion, reduced deep tendon reflexes, ataxia, confusion/cognitive disorder, loss

Neurovascular syndrome /

Postać mózgowo-naczyniowa

(8-30 Gy) of consciousness shortly after radiation exposure / Nudności, wymioty, ciężka biegunka, wysoka gorączka, zaburzenia elektrolitowe, drgawki, zniesienie odruchów głębokich, ataksja, zaburzenia poznawcze, utrata przytomności wkrótce po napromieniowaniu
2 days -2 weeks /

2 dni-2 tyg.

Damage to brain

nerve conduction /

Uszkodzenie przewodnictwa nerwowego w mózgu 
The human body's reaction to radiation depends upon several factors. The most important factors are as follows: an absorbed dose, a radiation type (alpha, beta, gamma, neutron radiation), radiation exposure, a kind and size of exposed tissue, age, health condition and what is crucial the quality of medical care provided incl. possibilities and skills of EMS to respond within first minutes and hours after radiation exposure [19].

Radiosensitivity of specific organs and tissues differ. Minor biological effects are noticed in sensitive organs such as testicles when exposed to radiation greater than $0.15 \mathrm{~Sv}$ causing temporary infertility or bone marrow affected by a dose of $0.5 \mathrm{~Sv}$ (impaired/weakened hematopoietic function) [20]. The above changes are in most cases temporary and leave no permanent effects. It appears that cells characterised by high proliferative activity and low maturity are particularly susceptible to radiation [21]. The most radiosensitive cells are the gonads, bone marrow and intestinal epithelium, while the least sensitive are nerve and muscle cells [22]. The term Acute Radiation Syndrome (ARS) is used to describe signs and symptoms of damage induced to organs and system that may lead to death within days or many months. ARS is also termed acute radiation sickness occurs when the whole body or its significant part receives radiation above a threshold dose of $1 \mathrm{~Gy}$ of gamma radiation (or $1 \mathrm{~Sv}$ ) over a short period of time. Dose fractionation over a period of time weakens radiation biological effects. The linear no-threshold (LNT) model implies the proportional dose-response relationship is expressed as a line and even the smallest dose close to zero always results in damage. The LNT model assumes that there is no threshold level below which adverse health effects such as ones of high-dose radiation occur. As mentioned above, doses between 0.5 and $1.0 \mathrm{~Sv}$ may have temporary effects; mainly a drop in lymphocyte count was observed [23]. Signs and symptoms of ARS are expected to occur after being exposed to a threshold dose of $1 \mathrm{~Gy}$. One of the most important indicator is the lethal dose within 60 days (LD50/60). It is the dose of radiation that leads to death to 50 percent of an exposed population in 60 days. The $L D 50 / 60$ is in the range from 3.5-4.0 Gy in patients managed without specialised care provided, $4.5-7 \mathrm{~Gy}$ when antibiotics and appropriate advanced treatment are provided and up to 7-9 Gy in patients with immediate access to intensive care units, reverse isolation and hematopoietic cell transplantation. Any exposure above the range 10-12 Gy is lethal [20].

It is paramount for the medical management of a radiation incident to determine whether a person has absorbed a threshold dose of ionising radiation above $1 \mathrm{~Gy}$ (or its equivalent $1 \mathrm{~Sv}$ ). A threshold dose of 1-6 Sv leads to the damage to hematopoietic system which is particularly radiosensitive and is followed by hematopoietic syndrome. Other organs are less affected. A threshold dose of 10-20 Sv damages intestinal epithelium (gastrointestinal syndrome), and a dose above $20 \mathrm{~Sv}$ leads to cardiovascular syndrome resulting from a sudden radiation damage to the central nervous system (CNS). There are four phases of ARS: prodromal, latent, manifest illness and recovery or death. The time course and severity of signs and symptoms for each subsyndromes of ARS may differ.
Reakcja organizmu osoby na ekspozycję zależy od wielu niezależnych zmiennych. Przede wszystkim od wielkości dawki pochłoniętej, rodzaju promieniowania (alfa, beta, gamma, neutronowego) i wielkości przekazywanej energii tego promieniowania, rodzaju i rozmiaru napromieniowanej tkanki, wieku i stanu zdrowia, oraz co niezmiernie ważne, jakości dostępnej opieki medycznej, w tym możliwości i umiejętności reagowania systemu ratowniczego w pierwszych minutach, godzinach po ekspozycji [19].

Poszczególne organy i tkanki przejawiają różną wrażliwość na promieniowanie. Niewielkie zmiany w organizmie pojawiają się we wrażliwych narządach już przy dawkach przekraczających 0,15 Sv dla jąder (przemijająca niepłodność) i 0,5 Sv dla szpiku kostnego (osłabienie funkcji krwiotwórczej) [20]. Są to na ogół zmiany przejściowe, ustępujące bez pozostawienia trwałych zmian.

Szczególną wrażliwość na promieniowanie wykazują komórki o dużej aktywności proliferacyjnej i jednocześnie cechujące się niską dojrzałością [21]. Do najbardziej wrażliwych komórek zaliczamy komórki gonad, szpiku kostnego, nabłonka jelitowego. Najmniej wrażliwe na promieniowanie jonizujące są natomiast komórki nerwowe i mięśnie [22]. Pojęcie ostrego zespołu radiacyjnego (ang. Acute Radiation Syndrome, ARS), obejmuje uszkodzenia różnych narządów i układów, które mogą doprowadzić do śmierci człowieka w różnym przedziale czasu: od kilku godzin po wiele miesięcy. Powszechnie zespół ARS określany jest mianem ostrej choroby popromiennej (OChP). Powstaje on w wyniku pochłonięcia przez całe ciało, lub znaczną jego część, dawki promieniowania przekraczającej wartość progową, za jaką przyjmuje się wartość 1 Gy promieniowania gamma (lub dawkę równoważną $1 \mathrm{~Sv}$ ). Aby uzyskać opisywany efekt chorobowy, dawka promieniowania musi zostać przekazana w krótkim czasie. Frakcjonowanie dawki, rozłożenie jej w czasie osłabia efekt biologicznego działania. Zgodnie z hipotezą liniową zależność między dawką a skutkiem ma postać linii prostej i nawet najmniejsza dawka, bliska zerowej, zawsze przynosi szkodę. Hipoteza ta zakłada, że nie istnieje żaden próg, poniżej którego przestają występować skutki obserwowane po dużych dawkach promieniowania. Jak wspomniano wyżej, większe dawki w przedziale 0,5-1,0 Sv spowodują prawdopodobnie jedynie przejściowe zmiany, najczęściej we krwi, polegające na obniżeniu poziomu limfocytów [23]. Jako wartość graniczną, po której spodziewamy się wystąpienia skutków ostrego napromieniowania, przyjmuje się obecnie wartość 1 Gy. Jednym z najważniejszych wskaźników opisujących skutki ostrego napromieniowania jest pojęcie dawki śmiertelnej po 60 dniach (LD 50/60). Jest to dawka pochłonięta powodująca śmierć u $50 \%$ napromieniowanej populacji w ciągu 60 dni. Wartość LD 50/60 oszacowana na poziomie około 3,5-4,0 Gy występuje u osób leczonych bez specjalistycznego wsparcia. Przy bardziej zaawansowanej pomocy medycznej może przyjąć wartość 4,5-7 Gy, gdy zapewnione są antybiotyki i inne leczenie wspomagające. W wyjątkowych sytuacjach granica ta może zostać przesunięta nawet do 7-9 Gy u pacjentów z szybkim dostępem do oddziałów intensywnej terapii, możliwością izolacji w trakcie leczenia i przeszczepieniem komórek krwiotwórczych. Wartości powyżej 10-12 Gy uważane są powszechnie za śmiertelne [20].

Najważniejsze w procesie zarządzania pomocą medyczną $w$ wypadku radiacyjnym jest zatem ustalenie, czy osoba narażona na promieniowanie jonizujące pochłonęła dawkę promieniowania 
przekraczającą wartość progową 1 Gy (lub równoważną $1 \mathrm{~Sv}$ ). Przy dawkach ponad progowych w przedziale 1-6 Sv w pierwszej kolejności dochodzi do uszkodzenia najbardziej wrażliwego na promieniowanie jonizujące układu krwiotwórczego, co prowadzi do powstania postaci hematopoetycznej. Objawy uszkodzenia innych narządów występują w mniejszym nasileniu. Przy dawkach rzędu 10-20 Sv dominują objawy wynikające z uszkodzenia nabłonka jelitowego (postać żołądkowo-jelitowa), a przy wyższych może powstać postać naczyniowo-mózgowa wynikająca z nagłego uszkodzenia CSN. W przebiegu ostrego zespołu radiacyjnego wyróżnia się cztery fazy. wstępną (prodromalną), utajoną (latentną), właściwych objawów, fazę zejściową lub zdrowienia. W zależności od postaci ARS moment wystąpienia każdej z tych faz, czas ich trwania i intensywność objawów są mocno zróżnicowane.

\section{Prodromal phase}

The prodromal phase begins usually within first 48 hours, but may develop up to 6 days after exposure [24]. Signs and symptoms are characterised by depression, anxiety, nausea, vomiting, dizziness, headache and sleep disturbances. Symptoms may occur from minutes following high-dose exposure to ionising radiation or an hour or a few hours after exposure if doses were less. Depending on the dose, a prodromal phase is followed by either a latent phase (low doses) or a manifest illness phase (high doses). The assessment of the time course of signs and symptoms (especially nausea and vomiting) and their severity may indicate the approximate absorbed dose [25]. This radiation triage was primarily intended to be used in the aftermath of a nuclear war which would involve mass casualties. Today, the radiation incidents involve few casualties and thus the radiation triage is of lesser importance due to more accurate solutions to be employed such as lab blood tests (the dynamics of lymphocyte count changes, chromosome aberration analysis). More detailed analysis of radiation triage and laboratory diagnostic methods will be presented in the following subsequent paper where the medical management of radiation incidents is thoroughly discussed. Table 3 presents characteristics of the prodromal phase of acute radiation syndrome (ARS).

\section{Latent phase}

The latent phase following a prodromal phase is characterised by delusive improvement of signs and symptoms. Although patients seem to be recovering, a disease resulting from radiation-induced damage is developing. This phase lasts from a few days up to several weeks and the latent phase shortens as the initial dose increases. This phase is typical of a hematopoietic syndrome (1-10 Gy) and less common for a gastrointestinal syndrome $(10-20 \mathrm{~Gy})$. This phase is literally unnoticeable in other syndromes due to the extent of radiation-induced damage and

\section{Faza wstępna (prodromalna)}

Faza prodromalna występuję najczęściej w ciągu 48 godzin od momentu ekspozycji na promieniowanie, ale może rozwinąć się nawet do 6 dni po niej [24]. Wśród objawów dominują: złe samopoczucie, niepokój, nudności, wymioty, bóle i zawroty głowy, zaburzenia snu. Przy dużych wartościach pochłoniętego promieniowania objawy występują już po kilku, kilkunastu minutach, przy mniejszych - dopiero po godzinie lub kilku godzinach. Przy małych dawkach okres ten przechodzi w fazę utajenia, przy dużych praktycznie bezpośrednio do fazy pełnoobjawowej. Ocena upływu czasu od ekspozycji do momentu wystąpienia objawów (przede wszystkim nudności i wymiotów), a także ich intensywności, pozwala na orientacyjne określenie wielkości pochłoniętej dawki [25].

Ten model przesiewowego triage'u radiacyjnego (segregacji medycznej) planowany był do wykorzystania w warunkach totalnej wojny jądrowej, w której zakładano zaistnienie strat masowych na ogromną skalę. Współcześnie w incydentach radiacyjnych, w których odnotowuje się pojedyncze ofiary, ta forma przesiewowego triage'u ma mniejsze znaczenie. Dostępne są inne dokładniejsze metody oceny wielkości pochłoniętej dawki, których dokonuje się na podstawie badań laboratoryjnych (ocena dynamiki zmian poziomu limfocytów, ocena aberracji chromosomalnych). Szczegółowemu omówieniu triage'u i laboratoryjnych metod diagnostycznych poświęcona zostanie oddzielna publikacja dotycząca zasad organizacji pomocy medycznej w zdarzeniach radiacyjnych. Charakterystykę reakcji pierwotnej w zależności od pochłoniętej dawki zilustrowano w tabeli 3.

\section{Okres latentny}

Okres drugi charakteryzuje się zanikaniem wcześniej opisanych objawów. Pacjent pozornie powraca do zdrowia. W organizmie, w wyniku powstałych uszkodzeń, rozwija się jednak choroba. Zazwyczaj faza ta trwa od kilku do kilkunastu dni. Wraz ze wzrostem dawki pochłoniętej czas trwania tej fazy ulega skracaniu. Ten okres jest bardzo charakterystyczny dla postaci hematopoetycznej (1-10 Gy), w mniejszym stopniu dla zespołu żołądkowo-jelitowego (10-20 Gy). W pozostałych postaciach - ze względu na skalę uszkodzeń popromiennych organizmu, dynamiki zmian wynikających z reakcji na 
dynamics of changes resulting from reactions to that damage, and thus the deteriorating patient's condition. At the end of this phase, the manifestation of signs and symptoms are getting apparent since the most damaged organs or systems are critically malfunctioning. This period especially in the hematopoietic syndrome is characterised by the failure of the bone marrow and immune system, water-electrolyte imbalance resulting from progressive damage to gastrointestinal epithelium. Symptoms of changes in the central nervous system do not occur with such a clearly marked latency period. uszkodzenia i wynikającej z tego stanu pacjenta - praktycznie jest niezauważalny. Pod koniec tego okresu następuje manifestacja objawów wynikających z krytycznych zaburzeń funkcjonowania najbardziej uszkodzonych układów czy narządów. W postaci hematopoetycznej dochodzi do niewydolności układu krwiotwórczego i odpornościowego, w postaci żołądkowo-jelitowej - do poważnych zaburzeń gospodarki wodno-elektrolitowej wynikającej z postępującego uszkodzenia nabłonka jelitowego przewodu pokarmowego. Objawy uszkodzenia centralnego systemu nerwowego nie występują z tak wyraźnie zaznaczonym okresem latencji.

\begin{tabular}{|c|c|c|c|c|c|}
\hline \multirow[b]{2}{*}{ Symptoms / Objawy } & \multicolumn{5}{|c|}{ Dose value / Wartość dawki } \\
\hline & $1-2 \mathrm{~Gy}$ & 2-6 Gy & $6-8 \mathrm{~Gy}$ & $8-30 \mathrm{~Gy}$ & $>30 \mathrm{~Gy}$ \\
\hline $\begin{array}{l}\text { Nausea, vomiting / } \\
\text { Nudności, wymioty }\end{array}$ & $5-50 \%$ & $50-100 \%$ & $75-100 \%$ & $90-100 \%$ & $100 \%$ \\
\hline $\begin{array}{c}\text { Time of onset / Czas } \\
\text { wystąpienia }\end{array}$ & $2-6 \mathrm{~h}$ & $1-2 \mathrm{~h}$ & $10-60 \mathrm{~min}$ & $<10 \min$ & Minutes / Minuty \\
\hline Duration / Czas trwania & $<24 \mathrm{~h}$ & $24-48 \mathrm{~h}$ & $<48 \mathrm{~h}$ & $<48 \mathrm{~h}$ & $\begin{array}{c}\text { N/A } \\
(\text { death }<48 \text { h) / } \\
\text { Nie dotyczy } \\
(\text { śmierć }<48 \text { h) }\end{array}$ \\
\hline Diarrhoea / Biegunka & None / Brak & $\begin{array}{c}\text { Moderate / Lekka } \\
<10 \%\end{array}$ & $\begin{array}{c}\text { Severe / Silna } \\
>10 \%\end{array}$ & $\begin{array}{l}\text { Severe / Silna } \\
\quad>95 \%\end{array}$ & $\begin{array}{c}\text { Severe / Silna } \\
100 \%\end{array}$ \\
\hline $\begin{array}{l}\text { Time of onset / } \\
\text { Czas wystąpienia }\end{array}$ & - & $3-8 \mathrm{~h}$ & $1-3 \mathrm{~h}$ & $<1 \mathrm{~h}$ & $<1 \mathrm{~h}$ \\
\hline $\begin{array}{c}\text { Headache / Ból głowy } \\
\% \text { of incidents / } \\
\text { \% wystąpienia }\end{array}$ & Slight / Niewielki & $\begin{array}{l}\text { Mild / Umiarkowany } \\
50 \%\end{array}$ & $\begin{array}{c}\text { Mild / Umiarkowany } \\
80 \%\end{array}$ & $\begin{array}{l}\text { Severe / Silny } \\
80-90 \%\end{array}$ & $\begin{array}{c}\text { Severe / Silny } \\
100 \%\end{array}$ \\
\hline $\begin{array}{c}\text { Time of onset / Czas } \\
\text { wystąpienia }\end{array}$ & - & $4-24 \mathrm{~h}$ & $3-4 \mathrm{~h}$ & $1-2 \mathrm{~h}$ & $<1 \mathrm{~h}$ \\
\hline Fever / Gorączka & None / Brak & $\begin{array}{l}\text { Mild / Umiarkowana } \\
\text { 10-100\% }\end{array}$ & $\begin{array}{c}\text { Mild - High / Umiar- } \\
\text { kowana do wysokiej } \\
100 \%\end{array}$ & $\begin{array}{l}\text { High / Wysoka } \\
\text { (100\%) }\end{array}$ & $\begin{array}{l}\text { High / Wysoka } \\
\qquad(100 \%)\end{array}$ \\
\hline $\begin{array}{l}\text { Time of onset / } \\
\text { Czas wystąpienia }\end{array}$ & - & $1-3 \mathrm{~h}$ & $<1 \mathrm{~h}$ & $<1 \mathrm{~h}$ & $<1 \mathrm{~h}$ \\
\hline $\begin{array}{l}\text { CNS function / Ośrodko- } \\
\text { wy układ nerwowy }\end{array}$ & $\begin{array}{l}\text { No impairment / } \\
\text { Bez upośledzenia }\end{array}$ & $\begin{array}{l}\text { Cognitive impairment } \\
\text { / Upośledzenie funkcji } \\
\text { poznawczych }\end{array}$ & $\begin{array}{l}\text { Cognitive impairment } \\
\text { / Upośledzenie funkcji } \\
\text { poznawczych }\end{array}$ & $\begin{array}{c}\text { Incapacitation / } \\
\text { Niezdolność do } \\
\text { poruszania }\end{array}$ & $\begin{array}{l}\text { Convulsions, tremor, ata- } \\
\text { xia, lethargy, / Drgawki, } \\
\text { drżenie, ataksja, letarg }\end{array}$ \\
\hline
\end{tabular}




\section{Manifest illness phase}

The third stage of ARS is characterised by the full manifestation of organ or system dysfunctions. If a person survives this phase, recovery is likely [20]. The critical phase of the hematopoietic syndrome occurs within 3-4 weeks after the bone marrow injury that causes the inability to produce sufficient amount of blood cells that consequently leads to immunodeficiency. Damage to intestinal epithelium occuring after a few days impair water-electrolyte balance followed by cardiopulmonary failure [26]. In the cardiovascular syndrome, radiation-induced damage to the cerebrovascular endothelium, synaptic connections and the demyelination of myelin sheath around nerves resulting from a decline in the population of oligodendrocytes lead the cerebral edema, various neurological deficits and finally patient's death. Exposure to extremely high doses of radiation significantly damages intracellular structures (cell membranes) and intracellular enzymes (catalase, peroxidase) that causes cellular degradation and systemic poisoning.

\section{Recovery or death}

The last stage is recovery or death. It is difficult to predict whether the total radiation absorbed dose of ionising radiation is lethal for a particular patient. There are a few cases of patients who survived apparently lethal doses of radiation (Goiânia, Brazil). They involved radiation which was fractionated into smaller doses within a prolonged period of time. Additionally it penetrated body parts assumed to be "safe" from the biological effects' perspective [27]. Age and sex are important factors that are to be taken into consideration while assessing radiation risks. Men tend to be more susceptible (higher radiosensitivity of their immune system) to adverse effects of radiation than women. Children and adults over $40-45$ are more radiosensitive than adults under 40 [29]. Moreover, individual radioresistance must be taken into account [30]. In case of repeated exposures of the whole body or radiosensitive organs to subliminal doses, cumulative effects have been observed. The manifestations of health effects of such radiation are termed chronic radiation syndrome (CRS). Its nature and dynamics are distinct from acute radiation syndrome. Its health effects may occur after many years and are predominantly characterised by an increased frequency of tumor formation especially hematopoietic malignancies such as leukemias, lymphomas, thyroid cancers, bone cancers, gliomas, premature aging and life span shortening as well as sterility, damage to the genetic material in reproductive cells that may result in offsprings' congenital abnormalities, hormonal imbalance and cataract [17], [31].

\section{Okres rozwiniętych objawów}

W trzecim okresie choroba w pełni manifestuje swój kompletny obraz kliniczny w formie zdominowanej przez objawy pochodzące od uszkodzonych narządów i układów. Jeżeli organizm pacjenta poradzi sobie z tym etapem choroby, ma dużą szansę na powrót do zdrowia [20]. W postaci szpikowej dopiero po okresie 3-4 tygodni od uszkodzenia szpiku dochodzi do okresu krytycznego dla pacjenta, wynikającego z obniżenia odporności organizmu powstałego z braku możliwości regeneracji naturalnie obumierających komórek krwi. Skutki uszkodzenia nabłonka jelitowego objawiają się po kilku dniach w postaci zaburzeń gospodarki wodno-elektrolitowej doprowadzającej do niewydolności krążeniowo-oddechowej [26]. W zespole mózgowo-naczyniowym dochodzi do uszkodzenia śródbłonka naczyń mózgowych, połączeń synaptycznych oraz demielinizacji osłonek nerwowych spowodowanej spadkiem populacji oligodendrocytów. Zmiany te prowadzą do rozwoju obrzęku mózgu oraz licznych deficytów neurologicznych, które w konsekwencji skutkują śmiercią pacjenta. Przy szczególnie dużych dawkach promieniowania dochodzi do znacznego uszkodzenia struktur wewnątrzkomórkowych (błon komórkowych) oraz uszkodzeń enzymów wewnątrzkomórkowych (katalaz i peroksydaz). W konsekwencji następuje rozpad komórek i intoksykacja całego organizmu.

\section{Okres zdrowienia lub śmierci}

W tym okresie dochodzi do śmierci organizmu lub do rozpoczęcia procesu zdrowienia. W zależności od wspomnianych wyżej czynników trudno jest przewidzieć, czy dana wartość przyjętego promieniowania jonizującego dla danego pacjenta będzie letalna (śmiertelna). Pojedyncze przypadki przeżycia po przyjęciu dużej dawki promieniowania, uważanej za śmiertelną (Goiânia, Brazylia), wynikały ze sposobu napromienienia, tj. frakcjonowania dawki, rozciągnięcia jej w czasie i przyjęcia na określoną, bezpieczną z punktu widzenia skutków część ciała [27]. Wiek i płeć organizmu ma również znaczenie przy ocenie skutków napromieniowania. Układ immunologiczny u mężczyzn wykazuje większą niż u kobiet wrażliwość na negatywne skutki promieniowania [28]. Dzieci oraz osoby dorosłe powyżej 40-45 lat są bardziej podatne na promieniowanie niż osoby dorosłe poniżej 40 roku życia [29]. Nie można też wykluczyć osobniczej, indywidualnej odporności organizmu na promieniowanie [30].

W przypadku wielokrotnego narażenia na dawki podprogowe promieniowania może dojść do kumulacji dawki i przekroczenia wartości progowych dla całego ciała lub wrażliwych narządów. Te zmiany chorobowe określa się mianem przewlekłej choroby popromiennej (PChP). Charakter i dynamika zmian chorobowych $w$ tej postaci jest inna niż w ostrym zespole radiacyjnym. Zmiany chorobowe pojawiają się dopiero po kilku-kilkunastu latach. Do głównych skutków tej formy napromieniowania należy. zwiększona zapadalność na choroby nowotworowe (zwłaszcza nowotwory układu krwiotwórczego - białaczki i chłoniaki, nowotwory tarczycy, układu kostnego i glejaki), przyspieszone starzenie się organizmu i skrócenie czasu życia, bezpłodność, uszkodzenie genomu komórek płciowych skutkujące możliwością wystąpienia wad wrodzonych u potomstwa, zaburzenia hormonalne, zaćma [17], [31]. 


\section{Cutaneous radiation syndrome}

The cutaneous symptoms that occur after radiation exposure are caused by a combination of inflammatory processes and proliferation changes [32]. Cutaneous radiation syndrome (CRS) may be a prompt reaction to radiation exposure. The radiation damages connective tissues and the blood vessels of the dermis. Transient erythema has been observed a few hours after the radiation exposure to $2 \mathrm{~Gy}$ [30]. The process may take years. The prodromal phase may develop within minutes or hours after exposure and is transient in nature. The prodromal phase is characterised by erythema (reddening and rash), irritation and itchiness. Then, a latent phase (delusive) occurs and is characterised by momentary remission of prodromal symptoms. The following manifestation stage is characterised by such lesions as noticeable erythema, desquamation and itchiness of the skin. In severe cases, subepidermal blisters, ulceration and skin necrosis. Ulceration may not be extensive but can involve deeper structures, i.e. soft tissues and even muscles and bones [30]. Long-term effects include keratosis, hyperpigmentation, hypopigmentation, epidermal atrophy, fibrosis, ulceration, telangiectasias and extravasation [34-35]. The extent and dynamics of cutaneous responses depend on several factors such as a dose, type and intensity of radiation, individual radiosensitivity, the extent of radiation exposure, contamination and absorption and the volume of skin exposed. It has been proved that repeated exposure to radiation results in cumulative doses and increases the radiation-induced damage to the skin. The skin covering bony areas show higher sensitivity to radiation [36]. Basal-cell and squamous cell skin cancers may occur years after exposure [37]. Extensive damage to the skin alter LD50/60 and increase the risk of death after every radiation exposure irrespective of the absorbed dose [38]. Table 4 presents the onset of clinical signs of skin injury depending on the dose received.

Table 4. Characteristics of skin lesions depending on the absorbed radiation dose

Tabela 4. Charakterystyka zmian skórnych w zależności od pochłoniętej dawki promieniowania

\section{Ostry zespół skórny}

Objawy skórne pojawiające się po ekspozycji na promieniowanie są spowodowane przez połączenie procesów zapalnych i zmian proliferacyjnych [32]. Ostry radiacyjny zespół skórny (ang. Cutaneous Radiation Syndrome, CRS) może rozwinąć się zaraz po ekspozycji. W momencie działania promieniowania dochodzi do uszkodzenia tkanki łącznej oraz naczyń skóry. Przemijający rumień powstały w wyniku napromieniowania dawką 2 Gy zaobserwowano już kilka godzin po ekspozycji [30]. Proces ten może jednak trwać latami. Zazwyczaj w ciągu kilku minut do godziny po ekspozycji rozwija się stadium prodromalne, które ma charakter przejściowy. W tym czasie pojawia się zaczerwienienie skóry, któremu towarzyszyć może wysypka oraz uczucie swędzenia i pieczenia. Po nim występuje etap utajony, który charakteryzuje się chwilowym ustąpieniem objawów. W fazie manifestacji pojawia się wyraźny rumień, któremu towarzyszyć może łuszczenie i swędzenie skóry. W ciężkich przypadkach mogą wystąpić podskórne pęcherze, głębokie owrzodzenia, a nawet martwica skóry. Owrzodzenia skóry mogą obejmować małe obszary, ale rozciągać się głęboko w tkankę miękką, docierając nawet do leżących pod nią mięśni i kości [30]. Wśród przewlekłych następstw rozwija się: rogowacenie, hiper- lub hipopigmentacja, zanik naskórka, zwłóknienie popromienne, owrzodzenia, teleangiektazje, wynaczynienie krwi [34-35]. Wielkość i dynamika zmian zależy od kilku czynników, m.in. od dawki promieniowania, rodzaju promieniowania i jego mocy, indywidualnej wrażliwości na promieniowanie, wielkości ekspozycji, skażenia i skali absorpcji oraz rozmiaru narażonej na promieniowanie skóry. Wykazano, że przy wielokrotnych ekspozycjach dochodzi do kumulacji dawki promieniowania, co zwiększa uszkodzenie skóry, a ponadto skóra w miejscach przylegania do kości jest bardziej narażona na promieniowanie [36]. Zmiany nowotworowe - najczęściej w postaci podstawnokomórkowego i płaskonabłonkowego raka skóry - mogą pojawić się dopiero po latach od ekspozycji [37]. Znaczące obrażenia powłoki zmieniają LD 50/60 i zwiększają ryzyko śmierci przy każdej ekspozycji na promieniowanie, niezależnie od pochłoniętej dawki [38]. Charakterystykę zmian skórnych powstałych w zależności od wielkości dawki przedstawia tabela 4.

\begin{tabular}{ccc}
\hline Symptoms / Objawy & Dose range / Zakres dawki [Gy] & $\begin{array}{c}\text { Time of onset [days] / Czas wystapienia } \\
\text { objawów po narażeniu [dni] }\end{array}$ \\
\hline Erythema / Rumień & $3-10$ & $14-21$ \\
\hline Epilation / Depilacja & above / powyżej 3 & $14-18$ \\
\hline Dry desquamation / Suche złuszczenie & $8-12$ & $25-30$ \\
\hline Moist desquamation / Mokre złuszczenie & $15-20$ & $20-28$ \\
\hline Blister formation / Pęcherze & $15-25$ & $15-25$ \\
\hline Ulceration (within skin) / Owrzodzenia & above / powyżej 20 & $14-21$ \\
\hline Necrosis (deep penetration) / Martwica & above / powyżej 25 & above / powyżej 21 \\
\hline
\end{tabular}

Source / Źródło: J.T. Bushberg, Radiation Exposure and Contamination, https://www.merckmanuals.com/professional/injuries-poisoning/radiation-exposureand-contamination/radiation-exposure-and-contamination [43]. 


\section{Stochastic effects}

Stochastic effects are assumed to be dose-independent. It is believed that a dose rate may only cause the increase in the probability of disease occurrence. Stochastic effects have no threshold level, which means the effects may occur after low-dose radiation exposure [39]. Stochastic effects include leukemia, solid tumors and hereditary defects passed on to children [40]. Neoplastic transformations may occur many years after the exposure to radiation. Genetic alterations may appear in the subsequent generations which are difficult to be distinguished from the diseases of other origins. The occurrence of stochastic effects depend on ontogenic variability of genetic predisposition or irradiated area (body part) [1].

\section{Conclusion}

Various sources of radiation have always been present around us. Nuclear energy, medical devices producing radiation or containing radioactive material, diagnostic and measuring devices used in industry and radioactive waste repositories are the main sources of potential hazard sources. The amount of artificial radiation a man is exposed to increases every year. The risk of radiation incidents resulting from failures of radiation producing devices (diagnostics, radiotherapy), human error or intended use of radioactive materials for criminal purposes must be considered. We cannot exclude that incidents such as the Chernobyl or Fukushima disasters will reoccur in the near future. The use of radioactive materials has been the target of terrorists. The state security services are aware of the real risk of a "dirty bomb" being constructed and detonated. The authors of this paper intended to discuss the medical approach of radiation incidents and their effects. The authors believe that the post-cold war peace is deceptive and makes emergency services less alert towards the ionising radiation risks.

\section{Skutki stochastyczne}

Do skutków stochastycznych zalicza się te, w których nasilenie objawów jest niezależne od wielkości pochłoniętej dawki, a jej wielkość zwiększa wyłącznie prawdopodobieństwo zachorowania. Dla skutków tych nie istnieje dawka progowa - mogą pojawić się przy przyjęciu nawet najmniejszej dawki promieniowania [39]. Do skutków stochastycznych zaliczymy przede wszystkim białaczkę i guzy lite, a także zmiany dziedziczne ujawniające się u potomstwa [40]. Zmiany nowotworowe pojawiają się z różnym opóźnieniem czasowym (od kilku do nawet kilkudziesięciu lat). Zmiany dziedziczne mogą ujawnić się dopiero w kolejnych pokoleniach. Skutki te są trudne do odróżnienia od zachorowań wywołanych innymi przyczynami. Wystąpienie skutków stochastycznych uzależnione jest także od osobniczej zmienności, predyspozycji genetycznych czy miejsca (okolica ciała) przyjętego napromienienia [1].

\section{Podsumowanie}

Źródła promieniowania są stale obecne w naszym otoczeniu. Stanowią je: energetyka jądrowa, środki medyczne wytwarzające promieniowanie lub mające $w$ swoim składzie materiał promieniotwórczy, urządzenia diagnostyczne i pomiarowe wykorzystywane w przemyśle, magazyny przechowujące odpady. $Z$ roku na rok wzrasta wielkość dawki promieniowania, jaką otrzymujemy ze źródeł sztucznych. Zawsze należy zakładać możliwość wystąpienia zdarzenia radiacyjnego powstałego w wyniku awarii urządzeń emitujących promieniowanie jonizujące (diagnostyka, radioterapia), ludzkiej bezmyślności w posługiwaniu się źródłami promieniowania, czy celowego i świadomego wykorzystania materiałów promieniotwórczych w celach kryminalnych. Nie można wykluczyć, że zdarzenia podobne do incydentów w Czarnobylu czy Fukushimie powtórzą się w niedalekiej przyszłości. Materiały promieniotwórcze pozostają nadal w kręgu zainteresowania środowisk terrorystycznych. Ryzyko skonstruowania i zdetonowania „brudnej bomby” jest poważnie brane pod uwagę przez służby odpowiedzialne za bezpieczeństwo państwa. Autorzy w niniejszej publikacji pragnęli przybliżyć problematykę zdarzeń radiacyjnych od strony konsekwencji medycznych powstałych w wyniku napromieniowania. W opinii autorów zgubne poczucie bezpieczeństwa po zakończeniu „zimnej wojny” uśpiło czujność środowiska ratowniczego na zagrożenia ze strony promieniowania jonizującego.

\section{Literature / Literatura}

[1] Zdrojewicz Z., Szlagor A., Wielogórska M., Nowakowska D., Nowakowski J., Wpływ promieniowania jonizującego na organizm człowieka, "Family Medicine \& Primary Care Review" 2016, 18, 2, 174-179.

[2] Roczny Raport, Działalność Prezesa Państwowej Agencji Atomistyki oraz ocena stanu bezpieczeństwa jądrowego i ochrony radiologicznej w Polsce w 2018 roku, PAA Warszawa 2019, 47-50.

[3] Gale R.P, Lax E., Radiation: What It Is, What You Need to Know, Retrieved Knopf Doubleday Publishing Group, New York 2013.

[4] Chau N.D., Michalec B., Natural Radioactivity in Bottled Natural Spring, Mineral and Therapeutic Waters in Poland, "Journal of Radioanalytical and Nuclear Chemistry" 2008, 279 (1), 121-129, https://doi.org/10.1007/s10967-007-7276-6.

[5] Suarez-Navarro, J.A., Pujol L., Determination of Potassium 
Concentration in Salt Water for Residual Beta Radioactivity Measurements, "Radiation Measurements" 2004, 38 (2), 145-151, https://doi.org/10.1016/j.radmeas.2003.09.007.

[6] Bin S., Green. S., Beddoe A. H., The $40 \mathrm{~K}$ activity of one gram of potassium, "Physics in Medicine and Biology" 1997, 42 (2), 407-413, https://doi.org/ 10.1088/0031-9155/42/2/012.

[7] Moskal P., Jowzaee S., Promieniowanie naturalne z Ziemi i z Kosmosu, „Foton" 2012, 117, 4-7

[8] Jaworowski Z., Beneficial radiation, "Wiadomości Chemiczne" 1996, 50, 759-878.

[9] Krajewska-Kułak E., Turczyńska A., Piotr Kułak, Gościk E., Radiation Protection from the Point of View of Patients of the Radiology Department at the University Clinical Hospital in Białystok, "Nursing and Public Health" 2016, 6 (10), 29-38.

[10] Załącznik nr 3 do ustawy z dnia 13 czerwca 2019 r. (poz. 1593), Załącznik nr 4 do ustawy z dnia 29 listopada $2000 \mathrm{r}$. - Prawo atomowe (Dz. U. z 2018 r. poz. 792, 1669 i 2227 oraz z 2019 r. poz. 730).

[11] Karwowski A., Encyklopedia popularna. Wyd. XXII, Wydawnictwo Naukowe PWN, Warszawa 1992.

[12] Brandt A. M., Beton jako materiał osłon przed promieniowaniem jądrowym - przegląd, "Cement Lime Concrete", 18/80, nr 2, 115-128.

[13] Ustawa z dnia 13 czerwca 2019 r. o zmianie ustawy - Prawo atomowe oraz ustawy o ochronie przeciwpożarowej (Dz. U. 2019 poz. 1593, Rozdział 4b Strategia i polityka w zakresie rozwoju bezpieczeństwa jądrowego i ochrony radiologicznej).

[14] United Nations Scientific Committee on the Effects of Atomic Radiation. UNSCEAR 2006 Report. Effects of ionising radiation. Vol. I. Report to the General Assembly, with scientific annexes A and B. UNSCEAR; 2006, Available from URL: http://www.unscear.org/unscear/en/publications/2006_1. html [dostęp: 5.12.2019].

[15] Rudnicki T., Terlecki J., Działania biologiczne promieniowania jonizującego, F. Jaroszyk (red.), Biofizyka, PZWL, Warszawa, 2008, 769-770.

[16] Compton A. H. A., Quantum Theory of the Scattering of $X$-Rays by Light Elements, "Physical Review American Physical Society (APS)" 1923, 21 (5), 483-502.

[17] Fijuth J., Radiobiologia, w: Radiologia - Diagnostyka obrazowa RTG, TK, USG i MR, B. Pruszyński, A. Cieszanowski (red).), Wydawnictwo PZWL, Warszawa 2016, 76-77.

[18] Williams P. M., Fletcher S., Health Effects of Prenatal Radiation Exposure, "American Family Physician" 2010, 82 (5), 488-493.

[19] Radiation and Your Health Acute Radiation Syndrome: A Fact Sheet for Clinicians, https://www.cdc.gov/nceh/ radiation/emergencies/arsphysicianfactsheet.htm [dostęp: 12.12.2019].

[20] López M., Martín M., Medical Management of the Acute Radiation Syndrome, "Reports of Practical Oncology \& Radiotherapy" 2011, 16 (4), 138-146, https://doi. org/10.1097/GRF.0b013e3182510a73.

[21] Lass P., Kubicki A., Bojarski P., Sein J. A., Na pograniczu toksykologii i fizyki jądrowej - nietypowe wypadki radiacyjne. „Przegląd Lekarski” 2013, 70 (8), 638-642.

[22] Rubin P., Casarett. W.G. Clinical Radiation Pathology as Applied to Curative Radiotherapy, "Cancer" 1968, 22 (4), 767-778, https://doi.org/10.1002/1097-0142(196810)22:4<767::AID-CNCR2820220412>3.0.C0;2-7.

[23] Berger M. E., Christensen D. M., Lowry P. C., Jones O. W., Wiley A. L., Medical management of radiation injuries: current approaches, "Occupational Medicine" 2006, 56(3), 162-172, https://doi.org/10.1093/occmed/kql011.

[24] Waselenko J.K., Medical Management of the Acute Radiation Syndrome: Recommendations of the Strategic National Stockpile Radiation Working Group, "Annals of Internal Medicine" 2004, 140(12), 1037-1057, https://doi. org/10.7326/0003-4819-140-12-200406150-00015.

[25] Grammaticos P., Giannoula E., Fountos G., Acute radiation syndrome and chronic radiation syndrome, "Hellenic Journal of Nuclear Medicine" 2013, 16 (1), 56-59.

[26] Wieczorek A., Góźdź S., Zespół żołądkowo-jelitowy ostrej choroby popromiennej w: Medycyna zagrożeń i urazów radiacyjnych, Janiak M., Wójcik A., PZWL, Warszawa 2005, 67-71.

[27] José de Lima Valverde N., Ferreira da Silva J., Tantalean O.B., An update on three radiation accidents in South America, "Health Physics" 2010, 98, 868-871, https://doi. org/10.1097/01.HP.0000345070.33576.f9.

[28] Kossakowski S, Kossakowski A., Pozytywne aspekty działania na organizm promieniowania jonizującego, „Medycyna Ogólna" 1999, 5 (XXXIV), 2, 201-210.

[29] Laia H., Terradas M., Jordi Camps J., Martín M., Tusell L., Genescà A., Aging and Radiation: Bad Companions, „Aging Cell" 2015, 14 (2), 153-161, https://doi.org/10.1111/ acel. 12306.

[30] Bray F. N., Simmons B. J., Wolfson A. H., Nouri K., Acute and Chronic Cutaneous Reactions to lonising Radiation Therapy, "Dermatology and Therapy" 2016, 6 (2), 185-206, https:// doi.org/10.1007/s13555-016-0120-y.

[31] Rammaticos P. Giannoula E., Fountos G., Acute radiation syndrome and chronic radiation syndrome, "Hellenic Journal of Nuclear Medicine" 2013, 16 (1), 56-59.

[32] Peter R. U.,Gottlober P., Management of Cutaneous Radiation Injuries: Diagnostic and Therapeutic Principles of the Cutaneous Radiation Syndrome, "Military Medicine" 2002, 167, Suppl. 1, 110-112, https://doi.org/10.1093/milmed/167.suppl_1.110.

[33] Barabanova A. V., Acute radiation syndrome with cutaneous syndrome, w: The Medical Basis for Radiation - Accident Preparedness. The Clinical Care of Victims, Ricks R. C., Berger M. E., O'Hara F. M., (red.), New York 2020, 217-224.

[34] Peter R. U.: Klinische Aspekte des kutanen Strahlen Syndroms nach Strahlenunfällen-Erfahrungen von Goiania und Tschernobyl, „Aktuelle Dermatologi” 1993, 19, 364-667.

[35] Peter R. U., Gottlober P., Nadeshina N., Krahn G., Plewtg G., Kind P., Radiation lentigo: a distinct cutaneous lesion after accidental radiation exposure, "Archives of Dermatology" 1997, 133, 209-211, https://doi.org/10.1001/ archderm.133.2.209. 
[36] Jabłońska S., Majewski S., Uszkodzenia skóry czynnikami fizykalnymi, w: Choroby skóry i przenoszone drogą płciową, Wydawnictwo Lekarskie PZWL, Warszawa 2008, 200-204.

[37] Gottlober P., Bezold G., Krahn G., Peter R. U., Basal cell carcinomas occurring after exposure to ionising radiation, "British Journal Dermatology" 1999, 141 (2), 383-385, https://doi.org/10.1046/j.1365-2133.1999.03019.x.

[38] Ryan J. L., lonising Radiation: The Good, the Bad, and the Ugly, "Journal of Investigative Dermatology" 2012, 132 (3), 985-993, https://doi.org/10.1038/jid.2011.411.

[39] Hamada N., Fujimichi Y., Classification of Radiation Effects for Dose Limitation Purposes: History, Current Situation and Future Prospects, "Journal of Radiation Research" 2014, 55 (4), 629-640, https://doi.org/10.1093/jrr/rru019.

[40] Douple E. B., Mabuchi K., Cullings H., Preston D. L., Kodama K., Shimizu Y., Fujiwara S., Shore R. E., Long-Term Radiation-Related Health Effects in a Unique Human Population: Lessons
Learned from the Atomic Bomb Survivors of Hiroshima and Nagasaki, "Disaster Medicine and Public Health Preparedness" 2011, (CUP)5 (S1), 122-133, https://doi.org/10.1001/ dmp.2011.21.

[41] Bourguignon M. H., Gison P. A., Perez M.R., Michelin S., Dubner D., Di Giorgio M., Carosella E. D., Genetic and epigenetic features in radiation sensitivity: Part II: Implications for clinical practice and radiation protection, "European Journal of Nuclear Medicine and Molecular Imaging" 2005, 32, 351-368.

[42] Military Medical Operations Armed Forces Radiobiology Research Institute: Medical Management of Radiological Casualties, edition 2, April 2003.

[43] Bushberg J.T., Radiation Exposure and Contamination, https://www.merckmanuals.com/professional/injuries-poisoning/radiation-exposure-and-contamination/radiation-exposure-and-contamination [dostęp: 12.12.2019].
ARKADIUSZ TRZOS, M.D., PH.D. - specialising in disaster medicine, emergency medicine, extreme medicine; acting Head of the Department of Disaster Medicine and Emergency Care at the Jagiellonian University Medical College.

WIKTORIA KUD $Ł A$ - medical student. Interests: disaster medicine and extreme medicine.

KAROL ŁYZIŃSKI, PH.D. - medical rescue worker at the Kraków Emergency Medical Services; Assistant at the Department of Disaster Medicine and Emergency Care, the Jagiellonian University Medical College.

MICHAt KORMAN - medical student. Interests: extreme medicine and disaster medicine. President of the Extreme and Disaster Medicine Student Society at the Jagiellonian University Medical College, Faculty of Medicine, Chair of Anaesthesiology and Intensive Care.
DR N. MED. ARKADIUSZ TRZOS - specjalności: medycyna katastrof, medycyna ratunkowa, medycyna ekstremalna, p.o. Kierownik Zakładu Medycyny Katastrof i Pomocy Doraźnej Uniwersytetu Jagiellońskiego Collegium Medicum.

WIKTORIA KUDŁA - studentka medycyny. Zainteresowania: medycyna katastrof i medycyna ekstremalna.

DR N. O ZDR. KAROL ŁYZIŃSKI - ratownik medyczny w Krakowskim Pogotowiu Ratunkowym, asystent w Zakładzie Medycyny Katastrof i Pomocy Doraźnej Uniwersytetu Jagiellońskiego Collegium Medicum

MICHAt KORMAN - student medycyny. Zainteresowania: medycyna ekstremalna i medycyna katastrof. Przewodniczący Studenckiego Koła Naukowego i Medycyny Katastrof przy Zakładzie Medycyny Katastrof i Pomocy Doraźnej Uniwersytetu Jagiellońskiego Collegium Medicum. 